\title{
Téoros
}

Revue de recherche en tourisme

\section{Planning and Management of Community-Based Ecotourism in the Philippines}

\section{Donald Hawkins et Christopher Holtz}

Volume 17, numéro 3, automne 1998

Pratiques contemporaines de gestion dans le domaine du tourisme

URI : https://id.erudit.org/iderudit/1072177ar

DOI : https://doi.org/10.7202/1072177ar

Aller au sommaire du numéro

Éditeur(s)

Université du Québec à Montréal

ISSN

0712-8657 (imprimé)

1923-2705 (numérique)

Découvrir la revue

Citer cet article

Hawkins, D. \& Holtz, C. (1998). Planning and Management of Community-Based Ecotourism in the Philippines. Téoros, 17(3), 37-43.

https://doi.org/10.7202/1072177ar d'utilisation que vous pouvez consulter en ligne. 


\section{A N A L Y S E}

\section{Planning and Management of Community-Based Ecotourism in the Philippines}

Donald Hawkins, Ed.D and Christopher Holtz, M.P.P.A.

Ecotourism development is widely seen as a solution to unsustainable resource use in ecologically sensitive areas. Conservation groups and other non-governmental organizations, often with the support of bilateral and multilateral donor organizations, have invested enormous resources in developing environmentally friendly tourism attractions, particularly within local communities where they ideally represent an alternative livelihood to other, often environmentally harmful, economic activities. ${ }^{3}$ Success in these endeavors has been mixed; a critical failing point that is often identified in community-based ecotourism projects is a lack of substantial and coherent stakeholder involvement. ${ }^{2}$ This article will present a fieldwork " friendly " model for use by ecotourism planning professionals in conmunity-based ecotourism development. It will accomplish this through the presentation of a case study of this planning process in a coastal community in the Philippines. ment. ${ }^{3}$ This method is a significant departure from the familiar master planning approach that tends to rely heavily on expert consultant teams who typically operate in an apolitical or " closed " environment. As with all strategic planning approaches, the primary goal in strategic destination planning is to insure success in achieving long-term stakeholder goals. The fundamental difference, however, is that unlike an organization-oriented strategic planning model, strategic destination planning must consider and incorporate the objectives and values of destination stakeholders with widely varying capacities and agendas.

\section{STRATEGIC DESTINATION PLANNING FOR COMMU. NITY-BASED ECOTOURISM}

The strategic destination planning process described in this article applies the fundamental principles of organizational strategic planning to the special requirements of community-based ecotourism development. This participatory planning process is intended to encourage meaningful stakeholder participation and give a strategic focus to the ecotourism development process in the rural communities that are often targeted for such projects within biodiversity conservation and sustainable development programs.

Strategic destination planning produces a systematic framework for decision making that guides a rural community from its current situation to a preferred future state as an ecotourism attraction or destination. The participatory element of strategic destination planning reflects the inherently political nature of destination develop-

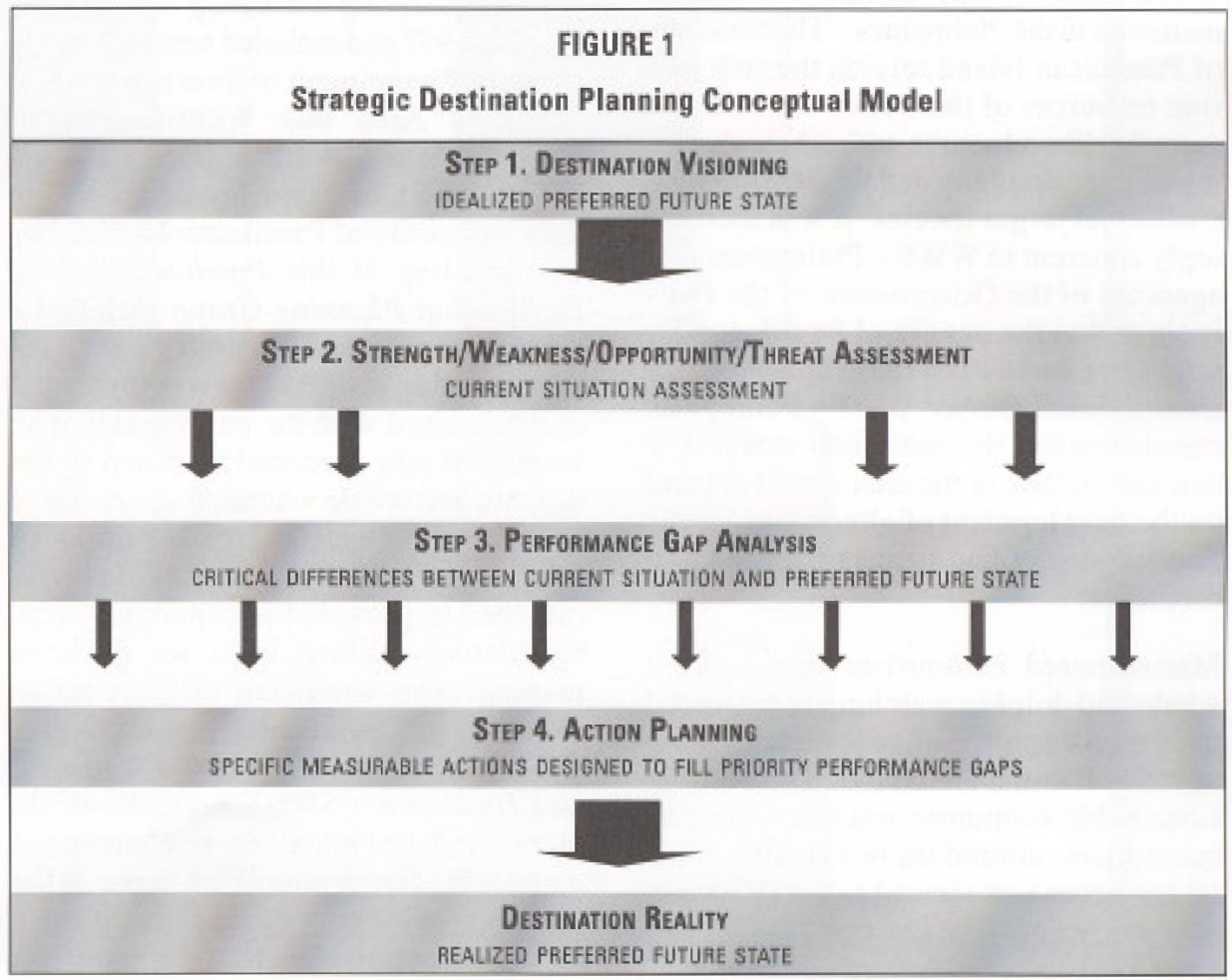


The conceptual framework of the strategic destination planning process described within this article is outlined in the following diagram. The process consists essentially of four steps. Step One requires participatory visioning among destination stakeholders to define a shared community vision of a preferred future state. Step Two requires the performance of a Strength, Weakness, Opportunity, and Threat (SWOT) assessment that outlines the current situation within a destination. Step Three asks the participating stakeholders to identify and prioritize critical internal and external performance gaps that represent the differences between the current situation and the shared vision. Finally, Step Four directly prioritizes and creates an implementation vehicle for achieving the destination vision with action plans designed to fill each of the identified priority performance gaps.

\section{PAMILACAN ISLAND, PHILIPPINES CASE BACKGROUND}

The four steps of the strategic destination planning process described above were utilized in conjunction with World Wildlife Fund - Philippines in the Pamilacan Island Dolphin and Whale Watching Village project in the summer of 1997. The waters around Pamilacan Island, Bohol, are one of the most critical habitats for marine mammals in the Philippines. ${ }^{4}$ The residents of Pamilacan Island rely on the rich marine resources of the Bohol Sea as a primary livelihood source with whale sharks, manta rays, dolphins, and whales being the traditional target species. It was increasingly apparent to WWF - Philippines and agencies of the Government of the Philippines that the people of Pamilacan Island were harvesting these species in an unsustainable manner. WWF-Philippines concluded that the continued survival of marine wildlife in the area would depend on the development of alternative livelihood strategies and species conservation measures.

Marine-based ecotourism centered on whale and dolphin watching represented one promising alternative livelihood strategy for Pamilacan Island. Developing sustainable economic activities, such as ecotourism, around these valuable natural resources was viewed as a way both to provide benefits to the community and contribute to conservation objectives.

\section{TABLE 1}

\section{Pamilacan Island Destination Vision Statement}

Pamilacan Island will be the first community-based marine ecotourism destination in the Philippines. Our goal is to provide one of the best do/phin and whale watching experience in Asia. The Pamilacan Island experience will offer nature lovers the opportunity to enjoy our community heritage and local marine habitat while learning about the numerous species of dolphins and whales that populate our coastal waters. The highlight of the Pamilacan Island tourism experience will be our dolphin and whale watching tour, marine mammals museum, and rich local culture. Tourism on Pamilacan Island will provide both sustainable economic atternatives to the island community and support for the conservation of the marine environment.

A community-based strategic destination planning process was initiated by WWF - Philippines, with the assistance of one of the authors of this article acting as a consultant. The four steps of the strategic destination planning process described previously were facilitated through a series of two planning workshops attended by the diverse group of stakeholders involved in the Pamilacan Island Dolphin and Whale Watching Village project. The processes and outputs of these workshops are described in detail below.

\section{PAMILACAN ISLAND STRA- TEGIC DESTINATION PLAN- NING SESSION I}

The first Pamilacan Island strategic destination planning workshop was held on July 31, 1997 and included representatives from the Department of Tourism (DOT), Protected Area and Wildlife Bureau (PAWB), World Wildlife Fund - Philippines (WWF), Baclayon Municipality, and the community of Pamilacan Island. The first meeting of this Pamilacan Island Destination Planning Group included a general overview of the strategic destination planning process that was presented and discussed with the participants. The workshop was preceded by a trip to the dolphin and whale watching operation at Bais, Negros Oriental, by the Pamilacan Island and WWF delegations that was intended to provide the community representatives with a basis for decision making. The workshop utilized group exercises and guided discussions to produce both a Destination Vision Statement and Destination SWOT Assessment. As mentioned previously, these elements of a Strategic Destination Plan serve as the basis for specific action plans designed to achieve the Pamilacan Island dolphin and whale watching project's objective of providing an attractive sustainable economic alternative for the island's whale shark fishermen.

While satisfactory outputs were produced during the workshop, the participation of the community representatives was minimal, which may have reflected the generally unenthusiastic "wait-and-see" approach to the project that the Pamilacan Island community had taken to that point. The prospect of a government ban on whale shark fishing was a primary concern of the community and represented a major obstacle to future mobilization of the grass roots support needed to succeed in community-based tourism endeavors.

The Pamilacan Island strategic destination planning workshop was the first step toward developing a participatory planning process that allowed each of the involved stakeholder groups to contribute to achieving long-term project objectives. This initial meeting established a foundation for the development of specific action plans by creating a shared vision of Pamilacan Island's future as a tourist destination. In addition, a planning group SWOT assessment clarified Pamilacan Island's current internal capacity and identified external factors that will impact the destination development process.

\section{PAMILACAN ISLAND DESTINATION VISION STATEMENT}

The goal of the planning group visioning exercise was to draft a Destination Vision Statement for Pamilacan Island. After evaluating a sample statement with the assistance of the facilitator, the workshop participants broke out into five small groups representing each of the planning 
group organizations. Each organization was tasked with producing a Destination Vision Statement for Pamilacan Island and presenting it to all participants. After extensive discussions of the five visions presented, the planning group agreed upon the following Pamilacan Island statement.

\section{PAMILACAN ISLAND STRENGTH/ WEAKNESS/ OPPORTUNITY/ THREAT ASSESSMENT}

The goal of the SWOT exercise was to jointly assess Pamilacan Island's strengths and weaknesses as a destination, as well

\section{TABLE 2}

\section{Planning Group Destination SWOT Matrix}

\begin{tabular}{|c|c|c|c|}
\hline STRENGTHS: & Mason & INTERMEDIATE & Mwar \\
\hline Marine mammal abundance and diversity & $\mathrm{x}$ & & \\
\hline Spotting skills of local fishermen & $\mathrm{x}$ & & \\
\hline $18^{\text {th }}$ century Spanish fort & $\mathrm{x}$ & & \\
\hline Peaceful and safe community & $\mathrm{x}$ & & \\
\hline Community heritage as a traditional whaling center & $\mathrm{x}$ & & \\
\hline Proximate coral reefs/dive sites & & $x$ & \\
\hline Friendly local people & & $\mathrm{x}$ & \\
\hline Small marine sanctuary & & $x$ & \\
\hline Sandy beaches & & & $x$ \\
\hline Availability of fresh seafood & & & $\mathrm{X}$ \\
\hline Presence of fossils & & & $x$ \\
\hline WEAKWESSES: & MajDh & INTERMEDIATE & Mison \\
\hline Lack of utility/drinking water & $\mathrm{x}$ & & \\
\hline Limited access to capital & $x$ & & \\
\hline Limited communication facilities & $x$ & & \\
\hline Inadequate management skills & $x$ & & \\
\hline Inadequate English language skills & $\mathrm{X}$ & & \\
\hline Limited transportation availability/access & $\mathrm{x}$ & & \\
\hline Lack of public bathroom (CR) facilities & $x$ & & \\
\hline Inadequate waste disposal/sanitation & $x$ & & \\
\hline Lack of boats fitted for dolphin/whale watching tours & $\mathrm{x}$ & & \\
\hline Limited health services & & & $\mathrm{x}$ \\
\hline Lack of mooring buoys/pier & & & $x$ \\
\hline Low community educational level & & & $\mathrm{x}$ \\
\hline OPPORTUNITIES : & MA.Jus & INTEBMEDIATE & Minos \\
\hline Development of the Panglao Island Tourism Estate & $\mathrm{x}$ & & \\
\hline Growth of fast-ferry routes to Tagbilaran City & $x$ & & \\
\hline Growth of ecotourism market & $x$ & & \\
\hline Increased awareness of conservation activities & $x$ & & \\
\hline Increased incomes for middle-class Filipinos & & $x$ & \\
\hline $\begin{array}{l}\text { Recognition of the Visayas as a dolphin/whale } \\
\text { watching destination }\end{array}$ & & $x$ & \\
\hline THAEATS : & MAJOR & INTEMMEDIATE & Minor \\
\hline Unpredictable weather/sea conditions & $x$ & & \\
\hline Drugs/prostitution/social upheaval & $x$ & & \\
\hline Pollution & $\mathrm{X}$ & & \\
\hline Exploitation of marine wildlife by other communities & $x$ & & \\
\hline Major tourism developments by outside investors & $x$ & & \\
\hline $\begin{array}{l}\text { Continued use of unsustainable fishing } \\
\text { methods in the area }\end{array}$ & $x$ & & \\
\hline Seasonality of whale sightings & & $x$ & \\
\hline National/regional political instability & & & $x$ \\
\hline
\end{tabular}

The participants identified a number of critical internal and external factors that will affect the course of Pamilacan Island's development as an ecotourism destination. With the ecotourism development consultant providing a measure of validity to the deliberations and their conclusions, the most important issues cataloged in the SWOT matrix for consideration in the destination development process were determined as follows:

\section{TABLE 3}

Staenghts

Marine mammal abundance

and diversity

$18^{\text {th }}$ Century Spanish fort

Dolphin and whale spotting skills of local fishermen and

Community heritage as a traditional whaling center

\section{WEAKMESSES}

Lack of boats fitted for dolphin/whale watching tours

Inadequate waste disposal/sanitation Inadequate management skills and Lack of public bathroom (CR) facilities

\section{Oppontunities}

Development of the Panglao Island Tourism Estate (designated tourism growth area)

Growth of fast-ferry routes to Tagbilaran City (nearest gateway) and

Recognition of the Visayas as a dolphin and whale watching destination

\section{ThreATS}

Unpredictable weather/sea conditions

Exploitation of marine wildlife by other communities and

Seasonality of whale sightings 
As these SWOT factors were incorporated into the strategic destination planning process, the objective will always be to build upon the strengths, ameliorate the weaknesses, capitalize on opportunities, and limit the threats.

\section{PLANNING SESSION I OBSERVATIONS}

The first Pamilacan Island strategic destination planning workshop successfully accomplished its objectives in terms of outputs, but it was unclear whether the inclusion of representatives from Pamilacan Island made a significant difference in securing meaningful " buy in " from the community. Participation by the four community representatives was limited. This may have been due to a lack of understanding because of intimidation at speaking out in a group, or a lack of interest and support for the process.

As noted in previous assessments of this project, the community appeared tentatively supportive but exhibited none of the genuine broad-based enthusiasm required for community-based tourism to succeed. ${ }^{5}$ Strong concerns remained that the project's real goal was to ban the whale shark fishing that represents the island's most important source of income. These reservations seemed to be the primary obstacle to securing the necessary community support, but it was also possible that the community simply lacked interest in pursuing tourism as an alternative source of income. As the process moved forward and opportunities for substantive involvement in tourism-related training programs was made available, a fuller assessment of the communities' willingness to commit to the development process was possible.

The participation of the mayor of the local municipality was very productive and confirmed the importance of his support for the project. The mayor was also somewhat cautious of the project because of the whale shark fishing ban issue, but seemed willing to make substantive contributions to the project, i.e. the creation of a solid waste management program for the island. He was very popular and extremely influential among the Pamilacan Island community and was the project's greatest asset in securing meaningful community support in the future.

\section{PAMILACAN ISLAND STRATEGIC DESTINATION PLANNING SESSION II}

The second Pamilacan Island strategic destination planning workshop was held on August 12, 1997 and included most of the same representatives from the Department of Tourism (DOT), Protected Area and Wildlife Bureau (PAWB), World Wildlife Fund - Philippines (WWF), Baclayon Municipality, and Pamilacan Island community that attended the first planning workshop.

As in the first workshop, group exercises and guided discussions were used to produce the meeting outputs. The key outputs of this second workshop were a performance gap assessment and a set of priority action plans. These elements of a strategic destination plan began to move from the planning process and preliminary visioning and assessment stage to the implementation and management.

Again, satisfactory outputs were produced during the workshop and the participation of the community representatives was more substantive than in the first meeting, although it was still difficult to encourage full participation in all the workshop exercises. It seemed that WWF and PAWB's pledge that the project was not designed to ban whale shark fishing allayed many community concerns. Dispelling these concerns was important and provided an opportunity to harness a broad base of community support for the project.

\section{PAMILACAN ISLAND PERFORMANCE GAP ASSESSMENT}

The purpose of the performance gap assessment in the strategic destination planning process was to identify the critical internal and external performance gaps between a destination's shared vision and its current situation. The performance gaps identified in the second planning workshop are the following (table 4).

Among these internal performance gaps, the key issues to be addressed were:

- Lack of trained dolphin and whale watching guides

- Lack of adequate nature interpretation facility

- Lack of boats fitted for dolphin and whale watching tours and

- Limited communication facilities

Among these external performance gaps, the key issues to be addressed were :

\begin{tabular}{|l|}
\multicolumn{1}{c|}{ TABLE 4} \\
$\qquad$ Internal Performance Gaps \\
\hline Lack of trained dolphin and whale watching guides \\
\hline Lack of adequate nature interpretation facility \\
\hline Lack of boats fitted for dolphin and whale watching \\
\hline Limited communications facilities \\
\hline Lack of appropriate management skills in the community \\
\hline Limited English speaking community members \\
\hline Lack of mooring buoys or pier \\
\hline Lack of community conservation education program \\
\hline Inadequate waste management capacity \\
\hline Lack of drinking or utility water \\
\hline $\begin{array}{l}\text { Insufficient data on the behavior and distribution of dolphins and whales in the vicinity of } \\
\text { Pamilacan Island }\end{array}$ \\
\hline Limited access to capital \\
\hline Limited community awareness of project goals and objectives \\
\hline
\end{tabular}


- Limited awareness of Pamilacan Island and its dolphin and whale watching tour's in target markets and

- Weak links to key distribution channels, i.e. tour operator's

\section{PAMILACAN ISLAND ACTION PLANNING}

The final step in the strategic destination planning process was the creation, implementation, and monitoring of action plans to move the destination from its current situation to its envisioned future state. Each element of the action plans was designed to increase its likelihood of implementation by detailing required resources, accountability, and critical success indicators to monitor implementation progress over time.

The six action plans that the Pamilacan Island Destination Planning Group developed at the second workshop are summarized below.

\begin{tabular}{|l|}
\multicolumn{1}{|c|}{ TABLE 5 } \\
\multicolumn{1}{|c|}{ External Performance Gaps } \\
\hline $\begin{array}{l}\text { Unpredictable weather/sea conditions } \\
\text { at certain times of the year }\end{array}$ \\
\hline $\begin{array}{l}\text { Seasonal presence of dolphins and } \\
\text { whales species }\end{array}$ \\
\hline $\begin{array}{l}\text { Limited awareness of Pamilacan Island } \\
\text { and its dolphin/whale watching tours in } \\
\text { target markets }\end{array}$ \\
\hline $\begin{array}{l}\text { Weak links to key distribution channels, } \\
\text { i.e. tour operators }\end{array}$ \\
\hline
\end{tabular}

\section{PLANNING SESSION II OBSERVATIONS}

As in the first workshop, satisfactory outputs were produced during the second meeting of the Pamilacan Island Destination Planning Group. Fortunately, the participation of the community representatives was more substantive than in the first meeting, although there was still some difficulty in encouraging full participation in all the workshop exercises. It seemed that WWF's and PAWB's pledge that the project was not designed to ban whale shark fishing allayed many community concerns. Dispelling these concerns was important and provided an opportunity to harness a broad base of community support for the project.
It seemed that the action planning process in particular generated genuine enthusiasm among the workshop participants and induced substantive discussions between the stakeholders on how to implement the project successfully.

\section{STRATEGIC DESTINATION PLANNING IMPLEMENTA. TION CONSIDERATIONS}

The strength of strategic destination planning lies in its reliance on participatory decision making among stakeholders, which tends to lead toward implementing actions that are consistent with shared long objectives. As Pamilacan Island moved from preliminary planning to implementation and actual operation of dolphin and whale watching tours, it faced new and often unanticipated challenges. In fact, the project has been temporarily placed on hold as one of the stakeholders groups, the Bureau of Fisheries and Aquatic Resources (BFAR), instituted a ban on whale shark fishing that re-ignited the mistrust of the community for the project as a whole. While BFAR was included in the initial stakeholder group, its involvement was clearly not sufficient and the unilateral decision to impose the whale shark ban was never raised with the planning group for discussion.

Nevertheless, The following issues were highlighted by the planning group and its facilitating consultant as being particularly important in the months leading up to initial tour operations.

\section{MONITORING AND ADJUSTING THE IMPLEMENTATION PROCESS}

The key to insuring successful implementation of the six action plans developed by the Pamilacan Island Destination Planning Group will be tigorous monitoring and compliance with the 30,60 , and 180 day target accomplishments. These act as critical success indicators (CSIs) in determining whether the responsible stakeholders were pursuing implementation in a timely manner. CSIs are a recognized component of organizational strategic plan modeling that allow for the measurement of progress in plan implementation. ${ }^{6}$ They are, in effect, the component of strategic destination planning that allow for the effective transition from "planning to doing" that can be such an obstacle in community-based ecotourism development. Given the importance of monitoring these CSIs, it is crucial that WWF, as the project coordinating organization, communicate with the various individuals tasked with the respective actions in order to monitor their progress. Holding these individuals and their organizations accountable for the action plan progress is the only way to insure successful implementation of the overall project.

As discussed in the overview of the conceptual planning model contained in Section 2.0 , strategic destination planning recognizes the inherently dynamic nature of destination development and requires both awareness and flexibility by the project coordinating organization of the ${ }^{44}$ on the ground "realities that are impacting implementation. In this case, it will mean that WWF's project manager and community organizing team must be sensitive to changes that affect action plan performance, and be able to make timely adjustments in the process to keep them on track.

It was strongly recommended that the Pamilacan Island Destination Planning Group convened for the two planning workshops described in this report continue to meet on a regular basis to monitor the development process. These group meetings may also serve as a forum to resolve misunderstandings or disputes among stakeholders before they have a negative effect on the overall project. The fact that this did not occur with BFAR and the ban on whale shark fishing underscores the importance of this continued effort to build a cohesive management structure. This informal planning group may eventually become the basis for a more structured Destination Management Organization (DMO) in the future. DMOs made up of public and private sector stakeholders are fast emerging as important players in the sustainable management of tourism destinations around the world.

\section{MANAGING COMMUNITY EXPECTATIONS}

Community consultation was an important part of the development process for the Pamilacan Island Dolphin and Whale Watching Village project since its inception and this must continue, and indeed be 
amplified, as it becomes operational. In these consultations, conveying an accurate depiction of the likely positive and negative impacts of tourism development to the Pamilacan Island community will be very important. Managing the expectations of the community in terms of anticipated job creation, revenue generation, and social disruption will be crucial to insuring that the people of Pamilacan Island remain supportive of the project.

\section{DEVELOPING A SOFT OPENING PLAN AND ENSURING SERVICE QUALITY}

The successful delivery of the initial dolphin and whale watching tours as a high quality ecotourism product is absolutely essential. The planned opening date was the beginning of the tourist high season, which meant that there was an excellent opportunity to present this new marine ecotourism product to a large group of international tourists and establish Pamilacan Island as the premier dolphin and whale watching destination in the Philippines. While the planned opening has been delayed by the BFAR whale shark fishing ban and the resulting community disruption, when the implementation process comes back " on-line ", tour operations will have to be thoroughly vetted in a soft opening period prior to the official opening date. In this soft opening period, the reservations or booking process, food preparation, and tour operations will be analyzed to identify and correct any service delivery fail points that exist.

A minimum of two weeks was recommended for that period to allow for a complete assessment of the service delivery process as well as time to make the necessary adjustments. The purpose of the soft opening period is to uncover the inevitable service delivery dilemmas and determine appropriate solutions. Particular attention should be paid to the following issues :

Are the tour schedules appropriate? Are guests picked up and returned on time ? Do they want to spend more time on one activity and less on another ?

- Are guests comfortable on the viewing boat?

- Do the guides give an adequate and meaningful interpretation of the dolphin and whale watching experience? Can they answer guests questions?

- Are guides, spotters, crew, and other front-line personnel friendly and helpful ?

- Is the food service adequate ?

- Can the logistical requirements of the tour operations, food service facility and gift shop/restroom facility be met as originally planned?

\section{CONCLUSION}

The traditional approach for the development of ecotourism projects-hiring an external consultant to collect data, assess the current situation, and make recommendations for the creation of the client's preferred outcomes - has clear benefits. It draws directly on the expertise and experience of the consultant and produces a coherent planning output in the form of a written report. Unfortunately, this report, though complete, logical, and filled with useful recommendations, often goes partially or wholly unutilized. It is the intention of this article to provide an alternative process that places a higher priority on building stakeholder consensus than on producing a perfectly reasoned analysis. The strength of the methodology detailed is its commitment to a participatory process and its ability to move a diverse group of stakeholders towards a common vision. The setback in the Pamilacan Island case not withstanding, WWF-Philippines has joined other conservation groups in supporting a stakeholder-based ecotourism development process that will yield more success stories in the effort to conserve biological diversity through the creation of sustainable livelihoods.

Christopher Holtz is a consultant specializing in the planning and development of sustainable tourism projects. He is currently working as the A sia/Pacific Program Manager for GREEN GLOBE, the environmental management program of the World Travel and Tourism Council, and oversees GREEN GLOBE's destination projects in the Philippines which include the Banawe Rice Terraces, a UNESCO World Heritage Site. Mr. Holtz has also worked as a consultant for World Wildlife Fund in the Philippines, assisting communities in the development of locally managed ecotourism projects.
Dr. Donald Hawkins is director of International Institute of Tourism Studies at the George Washington University. Professor in tourism, he has published several books and articles in this domain. He is more specifically interesting in tourism planification

Un comité de lecture a lu et aecepté ce texte

2 Conservation International, 1997:1.

3 In this context, the word political is not meant to be interpreted as referring to political partics and partisanship, but rather is used in a broader context that encompasses varying stakeholder objectives/values, negotiated decision making, and consensus building.

4 Pamilacan Island, Bohol (9 $\left.25^{\prime} \mathrm{N}, 124^{\circ} 10^{\circ} \mathrm{E}\right)$ is located approximately $700 \mathrm{~km}$ southwest of Manila and $70 \mathrm{~km}$ southeast of Cebu. The island has a land area of 135 hectares with about 200 households and a total population size of 1,119 .

5 Mendoza, 1996.

6 Goodstein, Nolan, ,Pfeiffer, J.W., 1993: 22.

\section{RÉFÉRENCES}

Conservation International (1997), Conservation International's Ecotourism Program Initiatives, Washington, DC.

Goodstein, L., Nolan, T., Pfeiffer, J.W., Applied Strategic Planning, New York, NY, (1993).

Mendoza, Gabino (1996), "s Preparations for the Development of Whale Watching as a Community Based Conservation Livelihood Program for Pamilacan Island, Bohol : Report on a Walkabout", March 22.

The Nature Conservancy (1995), Compatible Economic Development : Ecotourism, Washington, DC. 


\begin{tabular}{|c|c|}
\hline \multicolumn{2}{|c|}{ Action Puan No. 1 - Boat Reftting } \\
\hline Performance Gap & $\begin{array}{l}\text { Lack of boats fitted for } \\
\text { dolphin and whale watching }\end{array}$ \\
\hline $\begin{array}{l}\text { Brief Description of } \\
\text { Preferred Future State }\end{array}$ & $\begin{array}{l}\text { One boat refitted for dolphin and whale } \\
\text { Watching to act as a apilotw venture for } \\
\text { Pamilacan Island's community-basad } \\
\text { ecotourism project }\end{array}$ \\
\hline Action to be Developed & $\begin{array}{l}\text { Design and refitting of one boat for } \\
\text { dolphin and whale watching tours }\end{array}$ \\
\hline $\begin{array}{l}\text { Responsible } \\
\text { Person/Drganization }\end{array}$ & WWF \\
\hline $\begin{array}{l}\text { 30 Day Target } \\
\text { Accomplishment }\end{array}$ & $\begin{array}{l}\text { Identify boat owner willing to participate } \\
\text { in refitting program }\end{array}$ \\
\hline $\begin{array}{l}\text { 60 Day } \\
\text { Target Accomplishment }\end{array}$ & $\begin{array}{l}\text { Produce a satisfactory design for the boat } \\
\text { refitting for approval by the IATFMMC. }\end{array}$ \\
\hline $\begin{array}{l}180 \text { Day } \\
\text { Target Accomplishment }\end{array}$ & Refitting of the xpilotu boat begins. \\
\hline Action Completion Date & $2 / 15 / 98$ \\
\hline
\end{tabular}

\begin{tabular}{|l|l|}
\hline \multicolumn{2}{|l|}{ Action Plan No. 2-Gube Thaisisc } \\
\hline Performance Gap & No trained dolphin and whale watching guides \\
\hline $\begin{array}{l}\text { Brief Description of } \\
\text { Preferred Future State }\end{array}$ & $\begin{array}{l}\text { A committed group of tour guides capable } \\
\text { of providing an enjoyable and educational } \\
\text { dolphin and whale watching experience }\end{array}$ \\
\hline Action to be Developed & Guide training programs \\
\hline $\begin{array}{l}\text { Responsible } \\
\text { Person/0rganization }\end{array}$ & Siliman University \\
\hline $\begin{array}{l}\text { 30 Day } \\
\text { Target Accomplishment }\end{array}$ & Identify potential trainees \\
\hline $\begin{array}{l}\text { 60 Day } \\
\text { Target Accomplishment }\end{array}$ & $\begin{array}{l}\text { Develop training module in conjunction with } \\
\text { the Whale Conservation Society for approval } \\
\text { by the IATFMMC }\end{array}$ \\
\hline $\begin{array}{l}\text { 180 Day } \\
\text { Target Accomplishment }\end{array}$ & $\begin{array}{l}\text { Completion of the guide training program by } \\
\text { four guide trainees }\end{array}$ \\
\hline Action Completion Date & 2/198 \\
\hline \hline
\end{tabular}

\section{Action Plan No. 3 - Spamish Fort Restomanion}

\begin{tabular}{|l|l|}
\hline Performance Gap & No interpretive or support facilities \\
\hline $\begin{array}{l}\text { Brief Description of } \\
\text { Preferred Future State }\end{array}$ & $\begin{array}{l}\text { A high quality marine mammal museum and } \\
\text { bathroom/gift shap in the } 18^{\text {al }} \text { Century Spanish } \\
\text { Fort and its surrounding area. }\end{array}$ \\
\hline Action to be Developed & $\begin{array}{l}\text { Restoration of the } 18^{\text {th }} \text { Century Spanish Fort } \\
\text { into a marine mammals museum }\end{array}$ \\
\hline $\begin{array}{l}\text { Responsible } \\
\text { Person/Organization }\end{array}$ & Bookmark, Inc. \\
\hline $\begin{array}{l}\text { 30 Day } \\
\text { Target Accomplishment }\end{array}$ & $\begin{array}{l}\text { Restoration plans completed : } \\
\text { contractor bids submitted }\end{array}$ \\
\hline $\begin{array}{l}\text { 60 Day } \\
\text { Target Accomplishment }\end{array}$ & Restoration contract awarded \\
\hline $\begin{array}{l}\text { 180 Day } \\
\text { Target Accomplishment }\end{array}$ & Gift shop and restroom building completed \\
\hline Action Completion Date & 8/1/98 \\
\hline
\end{tabular}

\section{Action Plan No. 4 - Backimg Dfhet}

\begin{tabular}{|l|l|}
\hline Performance Gap & Limited communication facilities \\
\hline $\begin{array}{l}\text { Brief Description of } \\
\text { Preferred Future State }\end{array}$ & $\begin{array}{l}\text { A tourist reservations office in Baclayon } \\
\text { with fax machine and cell phone }\end{array}$ \\
\hline Action to be Developed & $\begin{array}{l}\text { Creation of booking office and purchase } \\
\text { of mecessary equipment }\end{array}$ \\
\hline $\begin{array}{l}\text { Responsible } \\
\text { Person/Organization }\end{array}$ & Baclayon Municipality \\
\hline $\begin{array}{l}\text { 30 Day Target } \\
\text { Accomplishment }\end{array}$ & Identify office location and needs \\
\hline $\begin{array}{l}\text { 60 Day } \\
\text { Target Accomplishment }\end{array}$ & $\begin{array}{l}\text { Canvassing for equipment purchase } \\
\text { completed }\end{array}$ \\
\hline $\begin{array}{l}\text { 180 Day } \\
\text { Target Accomplishment }\end{array}$ & Booking office manned and operational \\
\hline Action Completion Date & $2 / 197$ \\
\hline
\end{tabular}

\begin{tabular}{|c|c|}
\hline \multicolumn{2}{|c|}{ Action Plan Na, 5 - Feont line Trainime/Capacity Builoing } \\
\hline Performance Gap & $\begin{array}{l}\text { Lack of trained community member } \\
\text { to address the front-line and management } \\
\text { needs of an ecotourism project }\end{array}$ \\
\hline $\begin{array}{l}\text { Brief Description of } \\
\text { Preferped Future State }\end{array}$ & $\begin{array}{l}\text { A committed group of front-line and } \\
\text { management personnel from the community } \\
\text { to staff the dolphin and whale watching } \\
\text { ecotourism facilities. }\end{array}$ \\
\hline Action to be Developed & Creation of an appropriate training program \\
\hline $\begin{array}{l}\text { Responsible } \\
\text { Personvorganization }\end{array}$ & DOT \\
\hline $\begin{array}{l}30 \text { Day } \\
\text { Target Accomplishment }\end{array}$ & Training needs assessment completed \\
\hline $\begin{array}{l}\text { 60 Day } \\
\text { Target Accomplishment }\end{array}$ & $\begin{array}{l}\text { Training design completed: } \\
\text { potential trainees identified }\end{array}$ \\
\hline $\begin{array}{l}180 \text { Day } \\
\text { Target Accomplishment }\end{array}$ & 20 trainees complete the training program \\
\hline Action Completion Date & $2 / 1 / 98$ \\
\hline
\end{tabular}

\begin{tabular}{|c|c|}
\hline \multicolumn{2}{|c|}{ Agtion Plan No. 6 - Mamketing ano Promotion } \\
\hline Performance Gap & Limited awareness in the target markets \\
\hline $\begin{array}{l}\text { Brief Description of } \\
\text { Preferred Future State }\end{array}$ & $\begin{array}{l}\text { High profile for Pamilacan Island's dolphin } \\
\text { and whale watching tours in the targot } \\
\text { markets }\end{array}$ \\
\hline Action to be Developed & $\begin{array}{l}\text { Creation and coordination of promotional } \\
\text { strategy and materials }\end{array}$ \\
\hline $\begin{array}{l}\text { Responsible } \\
\text { Person/Organization }\end{array}$ & DOT - Regional Difice \\
\hline $\begin{array}{l}30 \text { Day } \\
\text { Target Accomplishment }\end{array}$ & $\begin{array}{l}\text { Brochure and poster design submitted } \\
\text { for approval by IATFMMC }\end{array}$ \\
\hline $\begin{array}{l}60 \text { Day } \\
\text { Target Accomplishment }\end{array}$ & $\begin{array}{l}\text { Brochures, posters, and other promotional } \\
\text { material created }\end{array}$ \\
\hline $\begin{array}{l}160 \text { Dey Target } \\
\text { Accomplishment }\end{array}$ & $\begin{array}{l}\text { FAM trips organized in conjunction with the } \\
\text { Bohol Association of Hotels, Restaurants, } \\
\text { and Resorts }\end{array}$ \\
\hline Action Completion Date & $2 / 1 / 98$ \\
\hline
\end{tabular}

